\title{
Effect of Traditional Pre-Culinary Hot Water Infusion Time on the Micronutrients and Health Protecting Phytochemicals in Heinsia crinita Leaf
}

\author{
Ufot Evanson Inyang \\ Department of Food Science and Technology, University of Uyo, Akwa Ibom State, Nigeria
}

\section{Email address:}

inyang.ufot@yahoo.com

\section{To cite this article:}

Ufot Evanson Inyang. Effect of Traditional Pre-Culinary Hot Water Infusion Time on the Micronutrients and Health Protecting Phytochemicals in Heinsia crinita Leaf. Journal of Food and Nutrition Sciences. Vol. 3, No. 5, 2015, pp. 191-195.

doi: $10.11648 /$ j.jfns.20150305.15

\begin{abstract}
One of the common traditional methods of improving the palatability and acceptability of Heinsia crinita leaves involves pre-culinary infusion of the cut leaves in already boiled water for period ranging from 5-20min or longer. In this study, the harvested leaves (dark variety) were washed in potable water, spread under shade to air dry, cut (2mm width) and shared into four equal portions of $1 \mathrm{~kg}$ each. Portions 2,3 and 4 were separately infused in hot water $(1: 3 \mathrm{w} / \mathrm{v})$ and maintained at $95^{\circ} \mathrm{C}$ for 5,10 and $15 \mathrm{~min}$, drained and cooled while the first portion was not treated with hot water (control). Each portion was oven dried $\left(50^{\circ} \mathrm{C}\right)$ for $36 \mathrm{~h}$, cooled, and packaged. The effect of the treatments on the minerals, vitamins and health benefiting phytochemicals were investigated. The untreated dried leaves had higher $\mathrm{K}, \mathrm{Ca}, \mathrm{Na}, \mathrm{Mg}, \mathrm{Fe}, \mathrm{Zn}$, ascorbic acid, beta-carotene, riboflavin, thiamine, alkaloids, flavonoids, saponins and tannins than the dried leaves from hot water infusion. Percentage losses of minerals, vitamins and health promoting phytochemicals to the infusion water that was discarded increased with increase in infusion time. Percentage losses of $\mathrm{K}, \mathrm{Ca}, \mathrm{Na}, \mathrm{Mg}, \mathrm{Fe}$ and $\mathrm{Zn}$ ranged from 11.01, 7.77, 16.72, 15.51, 9.55 and $8.50 \%$ for $5 \mathrm{~min}$ infused leaves to $34.34,18.73,45.07,41.76,24.85$ and $29.92 \%$ for $15 \mathrm{~min}$ infused leaves, respectively. Similarly, percentage losses of ascorbic acid, beta-carotene, riboflavin and thiamine ranged from 38.43, 15.69, 17.39 and $38.78 \%$ for $5 \mathrm{~min}$ infused leaves to $70.60,35.29,57.97$ and $68.38 \%$ for $15 \mathrm{~min}$ infused leaves, respectively. Losses of alkaloids, flavonoids, saponins and tannins ranged from $20.92,39.39,4.65$ and $16.67 \%$ for 5 min infused leaves to 62.24 , $69.70,10.08$ and $47.22 \%$ for $15 \mathrm{~min}$ infused leaves. The study demonstrated that for the consumers of $H$. crinita leaves to derive substantial nutritional and health benefits from the consumption of the leaf, it should be subjected to 5 min hot water infusion period prior to use for culinary preparation.
\end{abstract}

Keywords: Heinsia crinita, Hot Water Infusion, Micronutrients, Health Protecting Phytochemicals

\section{Introduction}

In today's traditional societies, nutrition and health care are interconnected and many vegetables are consumed as food in order to benefit health [1,2]. According to Sloan [3], foods are deemed more desirable for treating or managing chronic diseases than dietary supplements. Green leafy vegetables are valued mainly for their high mineral, vitamin and dietary fibre contents [4]. Some of them are equally medicinal and are used in the therapy of some diseases, majority of which have been reported to contain vital chemical compounds of medicinal importance $[5,6,7]$. They can therefore contribute to stemming the rising tide in noncommunicable chronic diseases prevalence in most communities. Furthermore, researchers have come up with the fact that some plant chemicals which were hitherto regarded as anti-nutrients have potentials of helping to reduce the risk of several deadly diseases in man $[6,8,9]$. Aletor and Adeogun [10] noted that some anti-nutritional phytochemicals exhibit protective effect, thus, making them to have dual purpose of reducing some essential nutrients and protecting the body against a number of biochemical, physiological and metabolic disorders.

Bush apple (Heinsia crinita) is one of the green leafy vegetables abundantly found in Akwa Ibom State, Niger Delta region of Southern Nigeria. It grows wild in the forest or selectively cultivated near the home [11]. It is a perennial rain forest shrub with woody stem and branches. It is called 
"atama" in Efik and Ibibio local dialect of Nigeria. It is classified as white or dark based on the taste and leaf colour by indigenes of Akwa Ibom State in Nigeria [7]. The two varieties resemble each other morphologically. However, the dark variety is greener and bitter than the white variety. Like other leafy vegetables, the harvested leaf has short shelf life. Consequently, most people trading on the leaf usually sun dried it and sold as dried product. The leaves of both varieties (fresh or dried) are used to prepare traditional soup called "atama" soup which is cherished by most consumers for its beautiful aroma and lasting sweet aftertaste in the mouth long after consumption [12].

Nutritionally, Heinsia crinita leaf is a good source of minerals and vitamins [11]. The crude protein and fibre contents of $15.10 \%$ and $13.90 \%$, respectively have been reported for the leaf [13]. It has for several years been exploited by traditional herbalists for the treatment of various ailments, including typhoid fever, diarrhea and candidiasis among other ailments [14]. Phytochemical screening of the leaf revealed the present of alkaloids, flavonoids, saponins, tannins, cardiac glycosides and terpenes among other compounds [7, 15]. This shows that the leaf possesses medicinal properties and could be used in the management of some of the diet related chronic diseases. It has been reported that the leaf extract showed significant $(p<0.05)$ antiplasmodial as well as hypoglycaemic and anti-diabetic effects that can be employed in health care [7].

One unique characteristic of Heinsia crinita leaf is that it has bitter taste that necessitates pre-culinary treatments to enhance palatability and acceptability of soup prepared with the leaf. Traditionally, the cut leaf is usually soaked in already boiled water for varying period ranging from five to twenty minutes or longer. Such treatment is capable of adversely affecting the water soluble and heat sensitive nutrients in the leaf as a result of leaching and thermal destruction. Oladele and Aborisade [16] noted that processing treatment given to leafy vegetables may lead to loss of some of the characteristics which initially made them consumer's delight. The current study was aimed at assessing the effect of varying the hot water infusion time on some micronutrients and health protecting phytochemicals in Heinsia crinita leaf.

\section{Materials and Methods}

\subsection{Material Procurement and Processing}

Twigs of Heinsia crinita (dark variety) were harvested from a garden at Mbiabong in Uyo Local Government Area of Akwa Ibom State, Nigeria. The leaves were destalked, washed in potable water, spread under a shade to air dry, cut (about $2 \mathrm{~mm}$ width) and shared into four equal portions of $1 \mathrm{~kg}$ each. The first portion which served as the control sample was oven dried at $50^{\circ} \mathrm{C}$ in a conventional air oven (model P.P. 22 US, Genlab, England) for 36h, cooled, packaged, labeled and stored at $4^{\circ} \mathrm{C}$ for analysis. The second, third and fourth portions were separately infused in hot water
$(1: 3 \mathrm{w} / \mathrm{v})$ and maintained at $95^{\circ} \mathrm{C}$ for 5,10 and 15 minutes, respectively, using a digital temperature control water bath (Grant Instruments, (Cambridge Ltd.), Herts SG8 6P2, England). The infused water was drained off and discarded. The infused leaf portions were immediately cooled separately, oven dried at $50^{\circ} \mathrm{C}$ in a conventional air oven for $36 \mathrm{~h}$, cooled, packaged, labeled and stored at $4^{\circ} \mathrm{C}$ for various determinations.

\subsection{Methods of Analysis}

The minerals (K. Ca, Na, Mg, Fe and $\mathrm{Zn}$ ) were determined using atomic absorption spectrophotometer (UNICAM, Model 939, UK) as described in AOAC [17]. Ascorbic acid, beta-carotene, riboflavin and thiamine were determined using the methods described in AOAC [17]. Alkaloid and flavonoid were determined using the method of Harborne [18]. Saponin and tannins were determined by AOAC [17] methods.

\subsection{Statistical Analysis}

Data obtained were subjected to One Way Analysis of Variance (ANOVA) using SPSS version 18 statistical package (SPSS, Inc., USA) to determine variation between treatments. Means of data generated were separated using Duncans Multiple Range Test (DMRT). Results were expressed as means \pm SD (standard deviation) of triplicate determinations. Significant variation was accepted at $\mathrm{p}<0.05$.

\section{Results and Discussion}

\subsection{Effect of Treatment on Minerals}

Table 1. Effect of infusion time on the mineral contents in dried Heinsia crinita leaf ( $\mathrm{mg} / \mathrm{l} 00 \mathrm{~g})$.

\begin{tabular}{lllll}
\hline \multirow{2}{*}{ Mineral } & \multicolumn{4}{l}{ Infusion Time $(\mathbf{m i n})$} \\
\cline { 2 - 5 } & $\mathbf{0}$ & $\mathbf{5}$ & $\mathbf{1 0}$ & $\mathbf{1 5}$ \\
\hline \multirow{2}{*}{$\mathrm{K}$} & $395.26 \mathrm{a} \pm 1.04$ & $351.73 \mathrm{~b} \pm 0.64$ & $313.08 \mathrm{c} \pm 1.22$ & $259.51 \mathrm{~d} \pm 0.90$ \\
& $(0.00)$ & $(11.01)$ & $(20.79)$ & $(34.34)$ \\
$\mathrm{Ca}$ & $763.90 \mathrm{a} \pm 1.12$ & $704.58 \mathrm{~b} \pm 0.91$ & $649.21 \mathrm{c} \pm 0.00$ & $620.84 \mathrm{~d} \pm 1.13$ \\
& $(0.00)$ & $(7.77)$ & $(15.00)$ & $(18.73)$ \\
$\mathrm{Na}$ & $57.82 \mathrm{a} \pm 0.92$ & $48.15 \mathrm{~b} \pm 1.11$ & $40.60 \mathrm{c} \pm 0.58$ & $31.76 \mathrm{~d} \pm 0.64$ \\
& $(0.00)$ & $(16.72)$ & $(29.78)$ & $(45.07)$ \\
$\mathrm{Mg}$ & $115.58 \mathrm{a} \pm 0.13$ & $97.65 \mathrm{~b} \pm 0.20$ & $85.70 \mathrm{c} \pm 0.18$ & $67.32 \mathrm{~d} \pm 0.00$ \\
& $(0.00)$ & $(15.51)$ & $(25.85)$ & $(41.76)$ \\
$\mathrm{Fe}$ & $18.59 \mathrm{a} \pm 0.48$ & $16.74 \mathrm{a} \pm 0.52$ & $15.06 \mathrm{a} \pm 0.23$ & $13.97 \mathrm{~b} \pm 0.16$ \\
& $(0.00)$ & $(9.55)$ & $(18.99)$ & $(24.85)$ \\
$\mathrm{Zn}$ & $6.35 \mathrm{a} \pm 1.11$ & $5.81 \mathrm{~b} \pm 0.80$ & $5.14 \mathrm{c} \pm 0.64$ & $4.45 \mathrm{~d} \pm 0.54$ \\
& $(0.00)$ & $(8.50)$ & $(19.53)$ & $(29.92)$ \\
\hline
\end{tabular}

Values are Means \pm SD (standard deviation) of triplicate determinations. Means on the same row with different superscripts are significantly different at $p<0.05$. Values in parenthesis indicate percentage mineral loss to the infusion water.

Table 1 show that Heinsia crinita leaf is a good source of mineral elements. The three most abundant minerals in the untreated leaves were calcium $(763.90 \mathrm{mg} / 100 \mathrm{~g})$, potassium $(395.26 \mathrm{mg} / 100 \mathrm{~g})$ and magnesium $(115.58 \mathrm{mg} / 100 \mathrm{~g})$, while zinc content was the least in value $(6.35 \mathrm{mg} / 100 \mathrm{~g})$. The physiological role of mineral elements in human diets has 
been documented [4, 23]. Calcium and magnesium for instance are important in the formation of bones and teeth [23]. Potassium has been shown to protect the body against the side effect of high sodium concentration.

Infusion of the leaves in hot water with the aim of reducing the bitterness and enhancing the palatability of the leaves resulted in significant $(\mathrm{p}<0.05)$ reductions in $\mathrm{K}, \mathrm{Ca}$, $\mathrm{Na}, \mathrm{Mg}, \mathrm{Fe}$ and $\mathrm{Zn}$ contents in the infused dried leaves. This may be attributed to the leaching of these minerals into the infusion water that was discarded. This result is in agreement with the findings of other researchers [19-21] who reported that various conventional food processing techniques such as blanching and cooking caused significant reductions in mineral contents of vegetables. Longer infusion times increased losses of all the minerals to the infusion water. Percentage reductions in $\mathrm{K}, \mathrm{Ca}, \mathrm{Na}, \mathrm{Mg}, \mathrm{Fe}$ and $\mathrm{Zn}$ ranged from 11.01, 7.77, 16.72, 15.51, 9.55 and $8.50 \%$ for 5 minutes infused and dried sample to $34.34,18.73,45.07,41.76,24.85$ and $29.92 \%$ for 15 minutes infused and dried sample, respectively. The generally lower levels of minerals in the leaves with infusion times agrees with the reports by Musa and Ogbadoyi [21] for Hibiscus sabdariffa leaves boiled for 5 and 10 minutes and Kawashima and Valente [22] for Tetragonia expansa blanched for 1, 5 and 15 minutes. Considering the importance of minerals in the human body as the structural components and regulators of body processes [23], the result suggests that minimal hot water infusion time $(5 \mathrm{~min})$ should be adopted in reducing the bitter taste in $H$. crinita leaf in order to reduce mineral losses. The result indicated that the mineral losses that occurred as a result of hot water infusion of the leaf notwithstanding, the infused and dried leaves still contained appreciable levels of minerals. It is anticipated that its continuous consumption would alleviate symptoms associated with these minerals deficiencies.

\subsection{Effect of Treatment on Vitamins}

Table 2. Effect of infusion time on the vitamin contents in dried Heinsia crinita leaf ( $\mathrm{mg} / \mathrm{l} 100 \mathrm{~g})$.

\begin{tabular}{lllll}
\hline \multirow{2}{*}{ Vitamin } & \multicolumn{5}{l}{ Infusion Time (min) } \\
\cline { 2 - 5 } & $\mathbf{0}$ & $\mathbf{5}$ & $\mathbf{1 0}$ & $\mathbf{1 5}$ \\
\hline Ascorbic & $102.41 \mathrm{a} \pm 0.16$ & $63.05 \mathrm{~b} \pm 0.24$ & $49.22 \mathrm{c} \pm 0.08$ & $30.10 \mathrm{~d} \pm 0.12$ \\
acid & $(0.00)$ & $(38.43)$ & $(51.94)$ & $(70.60)$ \\
Beta- & $1.53 \mathrm{a} \pm 0.33$ & $1.29 \mathrm{~b} \pm 0.11$ & $1.07 \mathrm{~b} \pm 0.50$ & $0.99 \mathrm{~b} \pm 0.24$ \\
carotene & $(0.00)$ & $(15.69)$ & $(30.07)$ & $(35.29)$ \\
Riboflavin & $0.69 \mathrm{a} \pm 0.22$ & $0.57 \mathrm{~b} \pm 0.10$ & $0.48 \mathrm{~b} \pm 0.00$ & $0.29 \mathrm{c} \pm 0.13$ \\
& $(0.00)$ & $(17.39)$ & $(30.44)$ & $(57.97)$ \\
Thiamine & $0.98 \mathrm{a} \pm 0.41$ & $0.60 \mathrm{~b} \pm 0.09$ & $0.42 \mathrm{c} \pm 0.21$ & $0.31 \mathrm{~d} \pm 0.56$ \\
& $(0.00)$ & $(38.78)$ & $(57.14)$ & $(68.38)$ \\
\hline
\end{tabular}

Values are Means \pm SD (standard deviation) of triplicate determinations. Means on the same row with different superscripts are significantly different at $\mathrm{p}<0.05$. Values in parenthesis indicate percentage vitamin loss to the infusion water.

The vitamin contents of the untreated dried $H$. crinita leaf (control) and hot water infused and dried leaf samples are presented in Table 2. The result shows that the untreated dried leaves had significantly $(\mathrm{p}<0.05)$ higher contents of ascorbic acid, beta-carotene, riboflavin and thiamine than the samples that were infused before drying. Losses of these vitamins increased with increase in infusion times. The reductions of ascorbic acid, riboflavin and thiamine may be attributed to leaching and thermal destruction of these vitamins [24, 25].

Ascorbic acid exhibited the highest reduction as a result of the treatment when compared with the other vitamins. Longer infusion times increased losses of ascorbic acid to the infusion water and the losses ranged from $38.43 \%$ for 5 min infused and dried leaves to $70.60 \%$ for $15 \mathrm{~min}$ infused and dried leaves. This result is in accordance with the verdict of other authors $[21,26]$ that the amount of ascorbic loss increases with cooking time. The high solubility of ascorbic acid in water and the relative ease with which it is oxidized make this vitamin particularly susceptible to processing conditions [27]. Human body cannot produce ascorbic acid, so it must be obtained entirely through ones diets. The protective action of fruits and vegetables has been attributed to the presence of anti-oxidants, especially anti-oxidant vitamins including ascorbic acid and beta-carotene [28, 29]. Considering the pivotal roles of this water soluble vitamin in human health, minimal infusion time $(5 \mathrm{~min})$ should be employed for $H$. crinita leaf in order to minimize its loss.

Beta-carotene is not soluble in water, but in fat and most organic solvents [24]. However, beta-carotene is known to be prone to oxidative destruction in the presence of heat, light, oxygen, enzymes and metallic ions [30]. The lower levels of beta-carotene in the leaves that were infused and dried could be attributed to the effect of hot water on the chloroplast and oxidation destruction during drying. Carotenoids are present in chloroplasts in the leaves of dark green vegetables [31]. Meyer [30] noted that when the cell is killed by blanching, drying or chemical reagents, the chloroplasts disintegrate and the carotene dissolves in the oil droplets. Thus, the loss of carotene is rapid in products that been blanched and then dehydrated [30]. Similar decreases in beta-carotene in blanched and dried non-conventional leafy vegetables had been reported [21, 32]. Infusion times had no significant effect $(p>0.05)$ on the beta-carotene content in the dried leaves. This result is in agreement with the report by Musa and Ogbadoyi [21] that longer blanching times (5 and 10 min) had no significant effect on beta-carotene content of Hibiscus sabdariffa. Beta-carotene is considered as the most important source of pro-vitamin A in carotenoid rich foods [30]. Vitamin A is needed in the body for vision, growth and differential of cells. As a strong anti-oxidant, beta-carotene may protect cells from oxidation damage, a possible major step in cancerogenesis [33].

Hot water infused and dried leaves had significantly $((p<0.05)$ lower riboflavin and thiamine contents than the untreated dried leaves. This could be attributed to possible leaching and thermal destruction of these vitamins [24, 25]. Similar observation was reported by Nkafamiya et al. [32] for blanched and dried non-conventional leafy vegetables. Higher losses of thiamine than riboflavin in the infused dried leaves could be due to the fact that thiamine is very soluble 
in water [24].

\subsection{Effect of Treatment on Health Benefiting Phytochemicals}

Table 3. Effect of infusion time on the phytochemical contents in dried Heinsia crinita leaf $(g / 100 g)$.

\begin{tabular}{lllll}
\hline \multirow{2}{*}{ Parameters } & \multicolumn{4}{l}{ Infusion Time (min) } \\
\cline { 2 - 5 } & $\mathbf{0}$ & $\mathbf{5}$ & $\mathbf{1 0}$ & $\mathbf{1 5}$ \\
\hline \multirow{2}{*}{ Alkaloid } & $1.96 \mathrm{a} \pm 0.31$ & $1.55 \mathrm{~b} \pm 0.18$ & $1.02 \mathrm{c} \pm 0.40$ & $0.74 \mathrm{~d} \pm 0.11$ \\
& $(0.00)$ & $(20.92)$ & $(47.96)$ & $(62.24)$ \\
\multirow{2}{*}{ Flavonoid } & $0.33 \mathrm{a} \pm 0.22$ & $0.20 \mathrm{~b} \pm 0.04$ & $0.16 \mathrm{~b} \pm 0.23$ & $0.10 \mathrm{~b} \pm 0.13$ \\
& $(0.00)$ & $(39.39)$ & $(51.52)$ & $(69.70)$ \\
\multirow{2}{*}{ Saponin } & $2.58 \mathrm{a} \pm 1.10$ & $2.46 \mathrm{a} \pm 0.09$ & $2.40 \mathrm{a} \pm 0.14$ & $2.32 \mathrm{a} \pm 0.52$ \\
& $(0.00)$ & $(4.65)$ & $(6.98)$ & $(10.08)$ \\
\multirow{2}{*}{ Tannin } & $0.36 \mathrm{a} \pm 0.91$ & $0.30 \mathrm{~b} \pm 0.32$ & $0.23 \mathrm{c} \pm 1.13$ & $0.19 \mathrm{~d} \pm 0.08$ \\
& $(0.00)$ & $(16.67)$ & $(36.11)$ & $(47.22)$ \\
\hline
\end{tabular}

Values are Means $\pm \mathrm{SD}$ (standard deviation) of triplicate determinations. Means on the same row with different superscripts are significantly different at $\mathrm{p}<0.05$. Values in parenthesis indicate percentage phytochemical loss to the infusion water.

Plants have basic nutritional importance by their content of protein, carbohydrate, fat, minerals, vitamins and water responsible for growth and development in man and animals. Much more than these, researchers have come up with the fact that some plant phytochemicals have potentials in helping to reduce the risk of several deadly diseases in man $[6-8]$. Alkaloids, flavonoids, saponins and tannins are among the phytochemicals contained in Heinsia crinita leaves that have been found to possess health promotion and protecting properties. Table 3 presents the levels of these phytochemicals in the untreated dried leaves (control) and hot water infused and dried leaves. The values of alkaloids, flavonoids, saponins and tannins in untreated dried $H$. crinita leaves were $1.96 \mathrm{~g} / 100 \mathrm{~g}, \quad 0.33 \mathrm{~g} / 100 \mathrm{~g}, \quad 2.58 \mathrm{~g} / 100 \mathrm{~g}$ and $\quad 0.36 \mathrm{~g} / 100 \mathrm{~g}$, respectively. Hot water infused and dried leaves had lower contents of these phytochemicals than untreated dried leaves. Longer infusion times increased losses of these important phytochemicals to the infusion water. Percentage losses of alkaloids, flavonoids, saponins and tannins ranged from 20.92, $39.39,4.65$, and $16.67 \%$ for $5 \mathrm{~min}$ infused and dried leaves to $62.24,69.70,10.08$ and $47.22 \%$ for 15 min infused and dried leaves, respectively. The lower levels of these phytochemicals in the infused and dried leaves relative to the untreated dried leaves could be attributed to a combination of thermal destruction and leaching of these compounds into the infusion water. Similar reductions of phytochemicals in other green leafy vegetables blanched in hot water had been reported by other authors [32, 34 and 35]. Owing to their strong physiological effect, alkaloids are of great value in medicine. They are believed to be among the plant chemical constituents responsible for hypoglycaemic effect in humans [36]. Flavonoids are strong anti-oxidants and free radical scavengers which prevent oxidative cell damage [23]. They also have strong anti-cancer properties and protection against cardiovascular diseases by inhibiting the oxidation of low density lipoprotein cholesterol [23, 37]. Saponins have been reported to decrease cholesterol absorption from the gastrointestinal tract and therefore lower blood cholesterol, a major risk factor for cardiovascular disease [23, 38]. Tannins on the other hand form complexes with protein and iron thereby inhibiting their bioavailability [23]. Besides these deleterious effects of tannins in the diet, they have anti-oxidant properties and may inhibit activation of carcinogens and cancer promotion [23]. This implies that tannins serve a dual role of reducing some essential nutrients and protecting the body against cancer. For the consumers to derive substantial benefits from the consumption of Heinsia crinita leaves, it is recommended that 5 minutes hot water infusion time should be employed.

\section{Conclusion}

This study demonstrated that Heinsia crinita leaf is a good source of micronutrients and health protecting phytochemicals. However, subjecting the leaf to hot water infusion for 5-15 minutes resulted in varying reductions in mineral, vitamins and health protecting phytochemicals. Percentage losses of minerals, vitamins and health protecting phytochemicals to the infusion water that was discarded increased with increase in infusion time. For the consumers to derive substantial nutritional and health benefits from the consumption of Heinsia crinita leaf, it is recommended that it should be subjected to 5 minutes hot water infusion period prior to use for culinary preparation.

\section{References}

[1] S. N. EL and S. Karakaya. Radical scavenging and iron chelating activities of some greens used as traditional dishes in Mediterranean diet. Int. Food Sci. Nutr. 55:67-74, 2004.

[2] N. M. Ansari, L. Houlihan, B. Hussain and A. Pieroni. Antioxidant activity of five vegetables traditionally consumed by South-Asian migrants in Bradford, Yorkshire, UK, Phytother. Res. 19:907-911, 2005.

[3] A. E. Sloan. The hierarchy of nutraceutical market $2000^{+}$: From positive eating to problem treating. J. Nutraceut. Med. Foods, 2(4):5-17, 2000.

[4] A. I. Ihekoronye and P. O. Ngoddy. Integrated Food Science and Technology for the Tropics. MacMillan Edu. Publishers, London, 1985, pp. 283-285.

[5] A. Sofowora. Medicinal Plants and Traditional Medicine in Africa. John Wiley and Sons Ltd., London, 1989, pp.12-146.

[6] V. V. Agte, K. V. Tarwadi, S. Mengale and S. A. Chiplonkar. Potential of indigenous green vegetables as natural sources of fortification of eight micronutrients. J. Food Comp. Anal. 13:885-891, 2000.

[7] J. E. Okokon, E. E. Umoh, E. I. Etim and C. L. Jackson. Antiplasmodial and antidiabetic activities of ethanolic leaf extract of Heinsia crinata. J. Med. Food, 12(1):131-136, 2009.

[8] G. Williamson, M. S. Dupont, R. K. Heaney, G. Roger and M. J. Rhodes. Induction of slutathione $\mathrm{S}$ transferas activity in hep G2 cells by extract of fruits and vegetables. Food Chem., 2:157-160, 1997. 
[9] K. T. Chung, I. Weichang and M. G. Johnson. Are tannins a double edged sword in biology and health? Trends Food Sci. Technol., 4:168-175, 1998.

[10] M. V. Aletor and O. A. Adeogun. Nutrient and anti-nutrient components of some tropical leafy vegetables. Food Chem., 53:375-379, 1995.

[11] E. U. I. Etuk, M. N. Bassey, U. O. Umoh and E. G. Inyang. Comparative nutrient studies on three local varieties of Heinsia crinata. Plant Var. Seeds. 11:151-158, 1998.

[12] I. Etukudo. Ethnobotany conventional and traditional uses of plant. The Verdict Press, Uyo, 2003, pp. 12-65.

[13] E. S. Eyo, F. Moline and A. J. Abel. Chemical composition and amino acid contents of Gnetum africana, Heinsia crinata and Piper guineense. Nig. J. Nutr. Sci., 4:57-62, 1983.

[14] I. E. Andy, M. E. Eja and C. I. Mboto. An-evaluation of the antimicrobial potency of Lasianthera africana (BEAUV) and Heinsia crinata (G. Taylor) on Escherichia coli, salmonella typhi, staphylococcus aureus and candida albicans. Malaysia J. Microbiol., 4(1):25-29, 2008.

[15] R. U. Ebana, A. I. Essien and O. D. Ekpo. Potential medicinal value of leaves of Lasianthera africana. Global J. Pure Appl. Sci., 1:2-7, 1995.

[16] O. O. Oladele and A. T. Aborisade. Influence of different drying methods and storage on the quality of Indian spinach (Basella rubra L.). Amer. J. Food Technol., 4:66-70, 2009.

[17] AOAC, Official methods of analysis ( $17^{\text {th }}$ edn.). Association of Official Analytical Chemists, Washington D. C., USA, 2000 .

[18] J. B. Harborne. Phytochemical Methods. Chapman and Hall Ltd., London, 1973, pp. 50-76.

[19] G. Oboh. Effect of some post-harvest treatments on the nutritional properties of Cnidoscolus acontifolus leaf. Pak. J. Nutr., 4:226-230, 2005.

[20] H. D. Mepha, L. Eboh and D. E. B. Banigo. Effects of processing treatments on the nutritive composition and consumer acceptance of some Nigerian edible leafy vegetables. Afr. J. Food Agric. Nutr. Dev., 7(1):1-18, 2007.

[21] A. Musa and E. O. Ogbadoyi. Effect of processing methods on some micronutrients, anti-nutrients and toxic substances in Hibiscus sabdariffa. Asian J. Biochem., 7:63-79, 2012.

[22] L. M. Kawashima and L. M. Valente Soares. Effect of blanching time on selective mineral elements extraction from the spinach substitute (Tetragonia expansa) commonly used in Brazil. Cienc Teenol. Aliment. Campinas, 25(3):419-424, 2005.

[23] M. B. Grosvernor and L. A. Smolin. Nutrition: From Science to Life. Harcourt College Publishers, New York, 2002, pp. 404-469.
[24] M. B. Jacob. The chemical analysis of food products $\left(3^{\text {rd }}\right.$ edn.). S. K. Jain, New Delhi, India, 1999, pp. 697-783.

[25] P. J. Fellows. Food Processing Technology: Principles and Practice. CRS Press LLC, Boca Raton, USA, 2000, pp. 233240, 312-352.

[26] F. M. Mathook and J. K. Imungi. Ascorbic acid changes in three indigenous Kenyan leafy vegetables during traditional cooking. Ecol. Food Nutr., 32:239-245,1994.

[27] S. S. Sobowale, O. P. Olatidoye, O. O. Olorode and O. K. Sokeye. Effects of preservation methods and storage on nutritional quality and sensory properties of leafy vegetables consumed in Nigeria. J. Med. Appl. Biosci., 2:46-56, 2010.

[28] G. Cao, E. Sofic and R. L. Prior. Antioxidant capacity of tea and common vegetables. J. Agric. Food Chem., 44:3426$3430,1996$.

[29] L. E. Grivetti and B. M. Ogle. Value of traditional foods in meeting macro - and micronutrients needs: The wild plant connection. Nutr. Res. Rev., 13:31-46, 2010.

[30] L. H. Meyer. Food chemistry ( $3^{\text {rd }}$ edn.). The AVI Publishing Company, INC., Westport, Connecticut, 1978, pp. 115-146.

[31] O. A. Odukoya, S. I. Inya-Agha, F. I. Segun, M. O. Sofidiya and O. O. Ilori. Antioxidant activity of selected Nigerian green leafy vegetables. Amer. J. Food Technol., 2(3):169-175, 2007.

[32] I. I. Nkafamiya, S. A. Oseameahon, U. U. Modibbo and D. Haggai. Vitamins and Effect of blanching on nutritional and anti-nutritional values on non-conventional leafy vegetables. Afr. J. Food Sci., 4(6):335-341, 2010.

[33] Roche. Beta-carotene: Nutrients and colur-colour and nutrients. F. Hoffman - La Roche Ltd., Switzerland, 1990, pp. $1-28$.

[34] A. S. Adeboye and J. M. Babajide. Effect of processing methods on antinutrients in selected leaf. Nig. Food J., 25(2):77-87, 2007.

[35] E. U. Onyeka and I. O. Nwambekwe. Phytochemical profile of some green leafy vegetables in South Eastern Nigeria. Nig. Food J. 25(1):67-76, 2007.

[36] W. L. Li, H. C. Zheng, J. Bukuru and N. De Kimpe. Natural medicines used in the traditional Chinese medical system for therapy of diabetes mellitus. J. Ethnopharmacol., 92:1-21, 2004.

[37] W. J. Criag. Phytochemicals: Guardians of our health. J. Amer. Diet Assoc., 97:199-204, 1997.

[38] D. L. Topping, G. B. Storer, G. D. Calvert and R. A. Meller. Effect of dietary saponins on fecal bile acid and neutral sterols, plasma lipids and lipoprotein turnover in the pig. Amer. J. Clin. Nutr., 33:783-786, 1980. 